\title{
Hypopharyngeal Cancer Pathologic Distant Metastasis TNM Finding v7
}

National Cancer Institute

\section{Source}

National Cancer Institute. Hypopharyngeal Cancer Pathologic Distant Metastasis TNM

Finding v7. NCI Thesaurus. Code C89040.

A pathologic finding about one or more characteristics of hypopharyngeal cancer,

following the rules of the TNM AJCC V7 classification system as they pertain to distant

metastases. There is no pathologic M0 for hypopharyngeal cancer. 